\title{
A Historical Record of Trace Metal Deposition In Northeastern Qinghai-Tibetan Plateau For The Last Two Centuries
}

\section{Shanying Li ( $\nabla 382559919 @ q q . c o m)$}

Nanjing Institute of Geography and Limnology Chinese Academy of Sciences

\section{Weiwei Sun}

Nanjing Institute of Geography and Limnology Chinese Academy of Sciences

\section{Rong Chen}

Nanjing Institute of Geography and Limnology Chinese Academy of Sciences

\section{Zhijie Zhang}

Research Institute of Petroleum Industry

\section{Dongliang Ning}

Nanjing Institute of Geography and Limnology Chinese Academy of Sciences

\section{Zhenyu Ni}

Nanjing Institute of Geography and Limnology Chinese Academy of Sciences

\section{Research Article}

Keywords: anthropogenic source, cadmium, accumulation fluxes, Lake Qinghai

Posted Date: May 19th, 2021

DOl: https://doi.org/10.21203/rs.3.rs-202374/v1

License: (a) (i) This work is licensed under a Creative Commons Attribution 4.0 International License. Read Full License

Version of Record: A version of this preprint was published at Environmental Science and Pollution Research on November 26th, 2021. See the published version at https://doi.org/10.1007/s11356-02117618-9. 


\section{Abstract}

Owing to rapid socio-economic development in China, trace metal emissions have increased and lakes even in remote areas have experienced marked changes in the last century. However, there are limited studies revealing long-term trends, anthropogenic fluxes and spatial characteristics of trace metals in lakes. In this study, we present a geochemical record from Lake Qinghai in the northeastern QinghaiTibetan Plateau and reconstruct trace metal pollution history during the last two centuries. The lacustrine sediment core was dated by ${ }^{137} \mathrm{Cs}$ and ${ }^{210} \mathrm{~Pb}$, and sediments deposited prior to the 1850 s were selected as the pre-industrial background. Factor analysis and enrichment factor indicated $\mathrm{Cr}$, $\mathrm{Cu}$ and $\mathrm{Ni}$ generally originated from natural sources, while $\mathrm{Cd}, \mathrm{Pb}$ and $\mathrm{Zn}$ have been influenced by human contamination since the mid-1980s. The anthropogenic Cd mainly derived from non-ferrous metal smelting in Gansu Province, and fluxes to Lake Qinghai sharply increased after the mid-1980s. The timing is similar to other lake sediment records from China and corresponds well with rapid economic development in China. The spatial pattern of anthropogenic $\mathrm{Cd}$ fluxes to lakes is primarily attributed to regional industrial emission, phosphate fertilizers and manure applied in agriculture.

\section{Introduction}

Aquatic ecosystems are habitats of great human importance as they provide essential water resource, help maintain biodiversity and regional ecosystem balance, as well as providing food (Brönmark \&Hansson 2002, Ricciardi \&Rasmussen 2001). In spite of their fundamental importance to humans, aquatic ecosystems have experienced unprecedented changes with rapid urbanization and industrialization, such as eutrophication and trace metal pollution, which have led to serious negative effects on the structure and function of these ecosystems (Dudgeon et al. 2006, Vanmaercke et al. 2015, Liu et al. 2013). Trace metals are among the most widespread of the various pollutants originating from anthropogenic activities, particularly from metal mining and smelting, burning of fossil fuels and agriculture (Evenset et al. 2007, Hosono et al. 2016, Kuwae et al. 2013, Mikac et al. 2011). Lacustrine sediments are generally recognized as a primary sink for the potentially harmful elements. However, trace metals such as cadmium ( $\mathrm{Cd})$, lead $(\mathrm{Pb})$, and zinc $(\mathrm{Zn})$ may be released back into the water column under favorable conditions and bioaccumulated in food webs, which is hazardous to human health (Liu et al. 2013). Therefore, it is necessary to consider the abundance, transport and persistence of trace metals as well as the effects of anthropogenic activities in the sediments.

In China, most of the previous studies have concentrated on large lakes from relatively populated areas, such as in the reach of the Yangtze River (Liu et al. 2012, Liu \&Shen 2014). Certainly, studies on these lakes are of great significance, as they are often heavily affected by human activities, while lakes in relatively remote areas were previously considered pristine ecosystems with limited anthropogenic impacts. However, investigations of relatively remote mountainous lakes in west China indicate that most of them have experienced considerable trace metal pollution (Bing et al. 2016, Jin et al. 2010, Lin et al. 2018, Liu et al. 2013, Zeng et al. 2014). These studies suggested that the trace metals are transported with aerosols and dusts over long distances. $\mathrm{Pb}$ is probably the most extensively investigated trace metal. 
However, knowledge of temporal trends, anthropogenic deposition fluxes and spatial characteristics are all still limited, which makes the understanding of the influence of human activities on regional to continental scale environmental quality unclear.

In this study, we present the temporal changes of trace metals in Lake Qinghai, which is the largest inland lake in China. The objectives of the study are first to determine the trace metal background values in Lake Qinghai sediments, then to reconstruct historical trends and distinguish anthropogenic contributions of trace metals, and further evaluate the spatial fluxes of anthropogenic sourced metals.

\section{Materials And Methods}

\subsection{Study region and field sampling}

Lake Qinghai $\left(36^{\circ} 32^{\prime}-37^{\circ} 15^{\prime} \mathrm{N}, 99^{\circ} 36^{\prime}-100^{\circ} 47^{\prime} \mathrm{E}\right)$, lies on the northeastern margin of the Qinghai-Tibetan Plateau at an altitude of about $3194 \mathrm{~m}$ above present sea level. It is a hydrologically-closed system with a surface area of about 4,260 km², and its catchment area is more than $29,660 \mathrm{~km}^{2}$. Catchment bedrock mainly consists of metamorphic and acidic igneous rocks while limestone outcrops are scattered throughout the western part of the catchment. The lake is fed mainly by direct rainfall and five large rivers and their tributaries, namely Buha, Shaliu, Hargai, Quanji, and Heima. The Lake Qinghai Basin region is mainly affected by a cold and semi-arid continental climate. In the winter, in the upper atmosphere westerlies prevail and in the lower atmosphere the polar cold air mass prevails. While in the summer, warm and humid air masses are transported by Asian summer monsoon from the tropical oceans. The mean annual air temperature is approximately $1.2^{\circ} \mathrm{C}$, mean annual precipitation is about $360 \mathrm{~mm}$, and the evaporation is about $3-4$ times higher than precipitation.

A gravity core with length of $26 \mathrm{~cm}$ named QH-9 was collected in the center area of the lake in November 2017(Fig. 1). Inspection of the cores at the time of sample collection indicated intact recovery of the sediment-water interface. The sediments were sliced at intervals of 1-cm in the field, sealed into polyethylene bags and stored in the cooler until they were returned to the laboratory.

\subsection{Establishing the chronology}

In the laboratory, the samples were freeze-dried and weighed before and after drying to calculate the water content and dry density. For dating, the weighed dry samples were sealed in plastic test tubes with caps. Radionuclides $\left({ }^{210} \mathrm{~Pb},{ }^{226} \mathrm{Ra}\right.$ and $\left.{ }^{137} \mathrm{Cs}\right)$ activities in samples were measured using an ORTEC HPGe GWL series well-type coaxial low background intrinsic germanium detector. The unsupported ${ }^{210} \mathrm{~Pb}\left({ }^{210} \mathrm{~Pb}_{\mathrm{ex}}\right)$ in each sample was obtained by subtracting the activity of ${ }^{226} \mathrm{Ra}$ from the total activity of ${ }^{210} \mathrm{~Pb}$ (Appleby 2001).

The Constant Rate of Supply (CRS) model is the most widely used ${ }^{210} \mathrm{~Pb}_{\mathrm{ex}}$ dating model within lacustrine deposits (Appleby 2001). The model assumes that the supply of ${ }^{210} \mathrm{~Pb}_{\mathrm{ex}}$ to the lacustrine sediment was constant, the age $t$ at mass depth $z$ is estimated using this model as follows: 
where $\mathrm{A}(0)$ is the total ${ }^{210} \mathrm{~Pb}_{\mathrm{ex}}$ inventory of the sediment core and $\mathrm{A}(\mathrm{z})$ is the total ${ }^{210} \mathrm{~Pb}_{\mathrm{ex}}$ inventory in the sediment core below mass depth $z$. When there is significant discrepancy between the results provided by the CRS model and ${ }^{137} \mathrm{Cs}$ chronostratigraphic marker, the peak of ${ }^{137} \mathrm{Cs}$ corresponding to the year $1963 \mathrm{CE}$ can be incorporated into the CRS model as a composite CRS Model to improve the final result (Appleby 2001). The age $t$ of each sediment layer between the surface and marked layer and below the layer is calculated as Eqs. (2) and (3), respectively:

$t=-\ln \left(1+\lambda^{\star}(\mathrm{A}(0)-\mathrm{A}(z)) / P\right) / \lambda(2)$

$t=\mathrm{T}_{0}-1963+\ln (\mathrm{A}(M) / \mathrm{A}(z)) / \lambda(3)$

$P=-\lambda^{\star}(\mathrm{A}(0)-\mathrm{A}(M)) /\left(1-\mathrm{e}^{-\lambda(\mathrm{T} 0-1963)}\right)(4)$

where $\mathrm{T}_{0}$ is the sample year, $P$ is the mean ${ }^{210} \mathrm{~Pb}_{\mathrm{ex}}$ flux during the period between sample year and 1963 $\mathrm{CE}, \mathrm{A}(M)$ is the total ${ }^{210} \mathrm{~Pb}_{\mathrm{ex}}$ inventory in the sediment core below the marked layer corresponding to the year $1963 \mathrm{CE}$.

\subsection{Geochemistry analysis and data processing}

For the geochemistry analysis, the freeze-dried samples were homogenized in an agate mortar, and then completely digested by $\mathrm{HCl}-\mathrm{HNO}_{3}-\mathrm{HF}-\mathrm{HClO}_{4}$ in Teflon beakers. The concentrations of aluminum (Al) and Zn were measured by inductively coupled plasma-atomic emission spectrometry (ICP-AES; Leeman Labs, Profile DV), while the concentrations of arsenic (As), Cd, chrome ( $\mathrm{Cr}$ ), copper (Cu), nickel (Ni), and Pb were measured by inductively coupled plasma mass spectrometry (ICP-MS; Agilent $7700 \times)$. The detection limits of the analytical procedure are 20 (Al), 1 (Ti), $0.2(\mathrm{Zn}), 0.1$ (As), $0.01(\mathrm{Cd}), 0.1(\mathrm{Cr}), 0.02(\mathrm{Cu}), 0.05$ $(\mathrm{Ni})$, and $0.01(\mathrm{~Pb}) \mathrm{mg} \mathrm{kg}^{-1}$, respectively. Data quality was ensured by measuring blanks and standard reference materials (GBW07358; Chinese geological reference materials) after every tenth sample. The accuracy, expressed as a recovery of the reference material, was $92.8-106.3 \%$ for the metals except for $\mathrm{Sb}$ (113.5\%). Factor analysis was performed using IBM SPSS19 statistical software for Windows to determine the relationships among the major and trace metals.

\section{Results}

\subsection{Sedimentary chronology}

The activity profiles of ${ }^{137} \mathrm{Cs},{ }^{210} \mathrm{~Pb}$ and ${ }^{226} \mathrm{Ra}$ are shown in Fig. 2a and $\mathrm{b}$. The first recognition of ${ }^{137} \mathrm{Cs}$ activity is at the mass depth of $4.37 \mathrm{~g} / \mathrm{cm}^{2}$ in the Core $\mathrm{QH}-9$, and the peak of the ${ }^{137} \mathrm{Cs}$ profile at the mass depth of $1.97 \mathrm{~g} / \mathrm{cm}^{2}$. Considering diffusion and post depositional mobility of the radionuclide in sediments, the accuracy of the first ${ }^{137} \mathrm{Cs}$ occurring position is difficult to identify due to the weak activity in the early stage. Nevertheless, the influence of diffusion and diagenetic processes did not significantly 
change the position of the maximum peak of ${ }^{137} \mathrm{Cs}$ in sediments. Thus, the ${ }^{137} \mathrm{Cs}$ peak at the mass depth of $\sim 1.97 \mathrm{~g} / \mathrm{cm}^{2}$ corresponds to about $1963 \mathrm{CE}$, which is similar with the widely recognized peak caused by the global fallout peak (Xu et al. 2010).

The ${ }^{210} \mathrm{~Pb}$ and ${ }^{226} \mathrm{Ra}$ activities generally reached equilibrium at mass depth of $7.36 \mathrm{~g} / \mathrm{cm}^{2}$, and the ${ }^{210} \mathrm{~Pb}_{\mathrm{ex}}$ profile did not follow the exponential variations with the mass depth (Fig. $2 \mathrm{~b}$ ). As shown in Fig. 2c, the CRS model underestimated the age of the sediments: the CRS model provided a date of $1987 \mathrm{CE}$ at the mass depth of $1.97 \mathrm{~g} / \mathrm{cm}^{2}$ in Core $\mathrm{QH}-9$, which deviated by $\sim 24$ years from the ${ }^{137} \mathrm{Cs}$ date. The deviations suggest variation in the supply rate of ${ }^{210} \mathrm{~Pb}_{\mathrm{ex}}$ in the northern basin of Lake Qinghai. Thus, the composite model was chosen to develop the age-mass depth model (Fig. 2c). The age for mass depth of $7.36 \mathrm{~g} / \mathrm{cm}^{2}$ is about $1841 \mathrm{CE}$, and the sediment accumulation rate ranges generally increased from 0.02 to 0.11 $\mathrm{g} / \mathrm{cm}^{2} / \mathrm{yr}$ during the period from the middle 19th century to the middle 20th century, and then the sediment accumulation rate decreased significantly to about $0.04 \mathrm{~g} / \mathrm{cm}^{2} / \mathrm{yr}$ (Fig. 2d).

3.2. Elemental concentrations in the sediments

The vertical distribution of $\mathrm{Al}, \mathrm{As}, \mathrm{Cd}, \mathrm{Cr}, \mathrm{Cu}, \mathrm{Ni}, \mathrm{Pb}$ and $\mathrm{Zn}$ are shown in Fig. 3, and the basic statistics of the trace metal concentrations are shown in Table 1. Factor analysis shows two factors that explain $84.2 \%$ of the data variance (Table 2 and Fig. 4). Factor 1 is represented by $\mathrm{Al}, \mathrm{Cr}, \mathrm{Ni}$ and $\mathrm{Cu}$ accounting for $44.3 \%$ of the data variance, while factor 2 is dominated by $\mathrm{Cd}, \mathrm{Pb}$ and $\mathrm{Zn}$ and it accounts for $39.9 \%$ of the total variance. In the Core $\mathrm{QH}-9, \mathrm{Al}, \mathrm{Cr}, \mathrm{Cu}$ and $\mathrm{Ni}$ concentration display similar vertical trends (Fig. 3). The values are generally steady prior to $1986 \mathrm{CE}$ and then followed by a gradual decrease in the upper layers of the core. In contrast, $\mathrm{Cd}, \mathrm{Pb}$ and $\mathrm{Zn}$ concentration generally show increasing trends since $1986 \mathrm{CE}$. However, As and Sb concentration do not show any similar trend with other elements, the concentrations are relatively stable prior to $1867 \mathrm{CE}$, then decrease from 1867 to $1986 \mathrm{CE}$, and subsequently increase to present.

Table 1. Geochemical composition of lacustrine sediments in Lake Qinghai compare with the UCC (Taylor and Mclennan, 1995), and background value in the soils of Qinghai Province (Chen et al., 2015). 


\begin{tabular}{|c|c|c|c|c|c|c|c|c|}
\hline & $\begin{array}{l}\text { Al } \\
(\mathrm{mg} / \mathrm{g})\end{array}$ & $\begin{array}{l}\text { As } \\
\text { (mg/kg) }\end{array}$ & $\begin{array}{l}\mathrm{Cd} \\
(\mathrm{mg} / \mathrm{kg})\end{array}$ & $\begin{array}{l}\mathrm{Cr} \\
(\mathrm{mg} / \mathrm{kg})\end{array}$ & $\begin{array}{l}\mathrm{Cu} \\
(\mathrm{mg} / \mathrm{kg})\end{array}$ & $\begin{array}{l}\mathrm{Ni} \\
(\mathrm{mg} / \mathrm{kg})\end{array}$ & $\begin{array}{l}\mathrm{Pb} \\
(\mathrm{mg} / \mathrm{kg})\end{array}$ & $\begin{array}{l}\mathrm{Zn} \\
(\mathrm{mg} / \mathrm{kg})\end{array}$ \\
\hline Range & $\begin{array}{l}35.1- \\
51.6\end{array}$ & $5.3-12.9$ & $\begin{array}{l}0.17- \\
0.63\end{array}$ & $\begin{array}{l}40.2- \\
53.0\end{array}$ & $\begin{array}{l}18.4- \\
23.9\end{array}$ & $\begin{array}{l}21.8^{-} \\
26.6\end{array}$ & $\begin{array}{l}17.6- \\
33.5\end{array}$ & $\begin{array}{l}51.5- \\
77.3\end{array}$ \\
\hline Average & 47.2 & 9.5 & 0.23 & 48.4 & 21.9 & 24.9 & 20.4 & 58.2 \\
\hline $\begin{array}{l}\text { Standard } \\
\text { deviation }\end{array}$ & 3.3 & 2.2 & 0.12 & 2.8 & 1.3 & 1.2 & 3.7 & 6.6 \\
\hline $\begin{array}{l}\text { coefficient } \\
\text { of } \\
\text { variation }\end{array}$ & 7.0 & 23.8 & 51.6 & 5.8 & 5.8 & 4.6 & 17.9 & 11.4 \\
\hline UCC & 80.4 & 1.5 & 0.10 & 35 & 25 & 20 & 20 & 71 \\
\hline Soils & - & 13.8 & 0.14 & 63.0 & 24.1 & 32.0 & 22.4 & 75 \\
\hline $\begin{array}{l}\text { Pre- } \\
\text { industrial }\end{array}$ & 48.5 & 11.4 & 0.18 & 49.9 & 22.4 & 25.2 & 19.5 & 55.7 \\
\hline
\end{tabular}

Table 2. Rotated component matrix for PCA loadings for trace metal concentrations of lacustrine sediments in Lake Qinghai.

\section{Discussion}

\begin{tabular}{|lll|}
\hline Element ratios & \multicolumn{2}{c|}{ Components } \\
\hline & PC1 & PC2 \\
\hline $\mathrm{Al}$ & $\mathbf{0 . 8 6}$ & -0.47 \\
\hline $\mathrm{Cd}$ & -0.06 & 0.21 \\
\hline $\mathrm{Cr}$ & -0.35 & $\mathbf{0 . 9 3}$ \\
\hline $\mathrm{Cu}$ & $\mathbf{0 . 9 4}$ & -0.29 \\
\hline $\mathrm{Ni}$ & $\mathbf{0 . 9 4}$ & -0.17 \\
\hline $\mathrm{Pb}$ & $\mathbf{0 . 9 6}$ & 0.11 \\
\hline $\mathrm{Zn}$ & -0.07 & $\mathbf{0 . 9 9}$ \\
\hline \% of variance & 44.3 & 39.9 \\
\hline \% of cumulative & & 84.2 \\
\hline
\end{tabular}

\subsection{Selection of background reference}

An estimation of reference background is required to accurately determine a regional contamination level, identify anthropogenic contribution and calculate inventory (Birch 2017). Empirical methods such as use 
of global mean concentrations of upper crust and marine shale, catchment geology and soils, and sedimentary core data have now been used extensively to determine natural metal concentrations (Birch 2017, Gloaguen \&Passe 2017, Song et al. 2014). Compared to the mean values of upper crust, lacustrine sediments of Lake Qinghai and background value in the soils of Qinghai Province are generally higher in As, Cd, Cr, and Ni concentrations (Chen et al. 2015, Taylor \&McLennan 1995). Thus, the use of catchment geology and soils, and sedimentary core might be more appropriate than using global concentration due to the detritus mainly derived from a local source (Bindler et al. 2011). In addition, a previous study found that the concentrations of $\mathrm{Cu}, \mathrm{Pb}$ and $\mathrm{Zn}$ in soils were higher in the northern and western of the Lake Qinghai catchment, suggesting human activities had influenced the virgin topsoil (Wang et al. 2015).

The use of sedimentary cores for determining pre-industrial samples as non-contaminated and background is now the most straightforward method (Birch 2017, Li et al. 2017, Lin et al. 2018, Song et al. 2014, Wan et al. 2016). Northwest China is considered to be a copper smelting center during the Bronze Age, and the geochemical analysis of anthropogenic and adjacent lacustrine sediments showed influence of metallurgical activity on the natural environment (Dodson et al. 2009, Li et al. 2011a, Zhang et al. 2017). For remote areas, increases in $\mathrm{Pb}, \mathrm{Cu}$ and $\mathrm{Zn}$ in Hongyuan peatland from the northeast QinghaiTibetan Plateau were also suggested to be correlated with the intensification of metallurgical activity at between 5.4- 4.0, 3.0- 2.5 and 2.0-1.0 cal ka BP (Yu et al. 2010). However, the Pb isotopic composition and $\mathrm{Pb} / \mathrm{Sc}$ ratios never varied beyond the range of soil weathering values and do not indicate a mining and smelting origin of the deposited $\mathrm{Pb}$ (Ferrat et al. 2012). The difference might be due to the trace metal concentrations within anthropogenic sediments decreased significantly from smelting sites (Bi et al. 2006, $\mathrm{Li}$ et al. 2015, Li et al. 2011b). Therefore, the established age model indicated that bottom sediments (17$26 \mathrm{~cm}$ ) were deposited prior to the 1850s, which could represent the pre-industrial background in Lake Qinghai.

\subsection{History of trace metal pollution and anthropogenic contribution}

To express the trace metal pollution, the enrichment factor $(\mathrm{EF})$ is calculated as:

$\mathrm{EF}=(\mathrm{M} / \mathrm{Al})_{\text {sample }} /(\mathrm{M} / \mathrm{Al})_{\text {back }}(5)$

where $\mathrm{M}$ is the concentration of the considered element, aluminum (Al) is used as the conservative element because anthropogenic sources are negligible and minimally influenced by post depositional diagenesis, and $(\mathrm{M} / \mathrm{Al})_{\text {sample }}$ and $(\mathrm{M} / \mathrm{X})_{\text {back }}$ are the ratios of the considered element and the reference element in the target and background samples, respectively (Bing et al. 2016, Kuwae et al. 2013, Lin et al. 2018). In this study, (M/Al) back is the ratio in the sediment dated prior to 1850s (Bing et al. 2016, Kuwae et al. 2013, Lin et al. 2018). The degrees of pollution may be classified in 5 scales $(1<\mathrm{EF} \leq 2$, minimal pollution; $2<\mathrm{EF} \leq 5$, moderate pollution; $5<\mathrm{EF} \leq 20$, significant pollution; $20<\mathrm{EF} \leq 40$, very high pollution; $\mathrm{EF}>40$, extremely high pollution) (Sutherland 2000). 
The EFs of $\mathrm{As}, \mathrm{Cd}, \mathrm{Cr}, \mathrm{Cu}, \mathrm{Ni}, \mathrm{Pb}, \mathrm{Sb}$ and $\mathrm{Zn}$ are presented in Fig. 5. The EFs of $\mathrm{Cr}$, $\mathrm{Cu}$ and $\mathrm{Ni}$ in the cores are close to 1 , indicating that the sediments are not enriched by these trace elements. The results of PCA analysis show that $\mathrm{Al}, \mathrm{Cr}, \mathrm{Cu}$ and $\mathrm{Ni}$ clustered in the same group, also indicating these metals generally originated from the natural sources because $\mathrm{Al}$ is a lithogenic element enriched in silicates and clay minerals. Relatively stable $\mathrm{Cd}, \mathrm{Pb}$ and $\mathrm{Zn}$ EFs of about 1 prior to mid-1980s suggest that sedimentary $\mathrm{Cd}$, $\mathrm{Pb}$ and $\mathrm{Zn}$ also mainly originated from natural detritus. The group including $\mathrm{Cd}, \mathrm{Pb}$ and $\mathrm{Zn}$ showed distinctly different features from the group of $\mathrm{Al}, \mathrm{Cr}, \mathrm{Cu}$ and $\mathrm{Ni}$, combining with subsequent increasing of EFs suggest that $\mathrm{Cd}, \mathrm{Pb}$ and $\mathrm{Zn}$ had been influenced by human contamination. Especially, the degree of Cd pollution had reached moderate level. In contrast, the EF of As referenced to the preindustrial background are obviously lower than 1 from 1867 to $1986 \mathrm{CE}$, and the absence of significant correlations between As and other elements in the sediments of Lake Qinghai, indicating a second-order diagenetic overprinting of the trace metal profiles over this period (Cooke \&Abbott 2008).

Assuming that $\mathrm{EF}>1$ indicates the presence of pollution, the anthropogenic contribution of metals can be calculated by the following equation:

$\mathrm{M}_{\text {anthro }}=\mathrm{M}_{\text {sample }}-\mathrm{Al}_{\text {sample }} \times(\mathrm{M} / \mathrm{Al})_{\text {back }}(6)$

where $M_{\text {anthro }}$ is the anthropogenic concentration of a considered metal (Shotyk et al. 2003). Accumulation flux is much more effective in reflecting the anthropogenic contribution than their concentrations due to large variation of the sediment accumulation rates (Bing et al. 2016, Li et al. 2017, Liu et al. 2013). The anthropogenic flux of the considered metal was calculated by multiplying the mass accumulation rate and the anthropogenic concentration in sediments at each depth:

$F_{M}=\operatorname{MAR} \times M_{\text {anthro }}(7)$

The temporal changes of total and anthropogenic fluxes of $\mathrm{Cd}, \mathrm{Pb}$ and $\mathrm{Zn}$ since $1841 \mathrm{CE}$ are shown in Fig. 6. The variations of $F_{C d}$ and $F_{P b}$ are consistent with the EFs (Fig. 5). $F_{C d}$ and $F_{P b}$ increased from nearly 0 before the 1980 s to a relatively high level $\left(0.03-0.17 \mathrm{mg} / \mathrm{m}^{2} / \mathrm{yr}\right.$ and $0.48-5.93 \mathrm{mg} / \mathrm{m}^{2} / \mathrm{yr}$, respectively) since the mid-1980s, corresponding to $33.2-76.1 \%$ and $6.3-49.3 \%$ of the total sedimentary metals, respectively. In contrast, $\mathrm{F}_{\mathrm{Zn}}$ show an obvious peak at about 1950 s but only accounting for $7.2 \%$ of sedimentary $\mathrm{Zn}$, indicating that $\mathrm{Zn}$ pollution during the period was diluted by the higher fluxes of natural debris.

\subsection{Spatio-temporal trends of Cd pollution in China}

Anthropogenic fluxes of Cd in our study increased from the mid-1980s. Similar enrichments in anthropogenic $\mathrm{Cd}$ from around 1980s have been recorded elsewhere in lacustrine sediments from China (Bing et al. 2016, Li et al. 2018, Lin et al. 2018, Wan et al. 2016, Zeng et al. 2014). However, the flux of anthropogenic $\mathrm{Cd}$ varies in different archives. In Lake Sayram from northwest China, the $\mathrm{F}_{\mathrm{Cd}}$ increased from 0.04 to $0.07 \mathrm{mg} / \mathrm{m}^{2} / \mathrm{yr}$ during the period 1990-2010 CE (Zeng et al. 2014). The average anthropogenic $\mathrm{Cd}$ accumulation was about $0.21 \mathrm{mg} / \mathrm{m}^{2} / \mathrm{yr}$ in Lake Gonghai from central China between 
1980 and 2014 CE, and the fluxes showed a dramatic increase during the early 1990s (Wan et al. 2016). In southwest China, Bing et al. (2016) investigated an alpine lake in the margin of Qinghai-Tibetan Plateau and showed that the $F_{\mathrm{Cd}}$ accumulated at about $0.68 \mathrm{mg} / \mathrm{m}^{2} / \mathrm{yr}$ since the mid-1980s, while Lin et al. (2018) reported that approximately $0.15 \mathrm{mg} / \mathrm{m}^{2} / \mathrm{yr}$ anthropogenic Cd deposited in Lake Lugu during this period. In western Lake Taihu from East China, a relatively high average $F_{\mathrm{Cd}}$ at about $0.94 \mathrm{mg} / \mathrm{m}^{2} / \mathrm{yr}$ was reported during the period 1980-2016 CE (Li et al. 2018). Compared with previous studies in China, the deposition of anthropogenic $\mathrm{Cd}$ in lakes is lower in northwest China than other region (Fig. 7).

It is well known that anthropogenic Cd deposition rates to sediment are strongly correlated with industrial emissions (Pacyna et al. 2009). The estimated industrial Cd emission from 1949 to 2012 CE in China showed Cd emission from primary anthropogenic sources increased from 15.5 to $526.9 \mathrm{t} / \mathrm{yr}$, also with the most rapid increase occurring since the mid-1980s (Tian et al. 2015). Industrial Cd emissions in China are mainly derived from non-ferrous metal smelting and coal consumption by industrial boilers (Tian et al. 2015). Shandong Province is characterized by rapid economy growth, there is a large volume of coal consumption and industrial output mean it is ranked as the province with the highest Cd emissions (Tian et al. 2015). In addition, nonferrous industries are flourishing in Jiangxi, Yunan, Anhui and Gansu Province, and poorly controlled smelting emissions have caused many areas in these provinces to have relatively higher emissions (Tian et al. 2012, Tian et al. 2015). Although there are few modern industries and the population density is low in the catchment of Lake Qinghai and even in wider Qinghai Province, anthropogenic $\mathrm{Cd}$ can be transported by the long-range atmospheric dust derived from the adjacent Gansu Province. For example, Jinchang is Chinese largest nickel producer and well known for its nonferrous metal production, and Baiyin is the base for non-ferrous metal mining in China. A number of large industrial enterprises were formed for $\mathrm{Pb}-\mathrm{Zn}, \mathrm{Cu}$ and polymetallic extraction since the 1970s. As estimated by Tian et al. (2015), 27 tons of Cd were discharged in 2010 CE with over $90 \%$ sourced from non-ferrous metal smelting in Gansu Province.

Cd is also added to agricultural land through rock phosphate fertilizers and manure (Luo et al. 2009, Zhang \&Shan 2008). The Cd contents in these fertilizers and manure in China range from $0.5-4.8 \mathrm{mg} / \mathrm{kg}$, which are significantly higher than the background of Chinese lacustrine sediments (Cheng et al. 2015, Luo et al. 2009). These fertilizers have been increasingly applied in China since the late 20th century, and the persistent application has led to $\mathrm{Cd}$ accumulation in the agricultural soils. In Chinese agricultural soils, livestock manures and fertilizers account for $63 \%$ of the total Cd inputs (Luo et al. 2009). With the steady increase in population and relative scarcity of agricultural land in China, agricultural cultivation in east China has been intensified with fertilizers and agrochemicals (Zhang \&Shan 2008). The catchment of Lake Taihu is not only one of Chinse most industrial developed areas, but has also intensified use for agriculture, with the concomitant increase in use of phosphate fertilizers and manure. These should be one of the main sources of $\mathrm{Cd}$ accumulation in the watershed and anthropogenic $\mathrm{Cd}$ in the lake. Similar findings have also been found in lacustrine records from Huaihe region, where is mainly influenced by agriculture (Zhang \&Shan 2008). Therefore, the spatial variation of $F_{C d}$ in the Chinese lakes may be related to different levels of economic development, population density and specific industries. 


\section{Conclusions}

In this study, changes in the trace metal concentrations and sources in sediments of Lake Qinghai are examined over the past two centuries. Compared with the pre-industrial background, $\mathrm{Cr}, \mathrm{Cu}$ and $\mathrm{Ni}$ generally originated from natural sources, while $\mathrm{Cd}, \mathrm{Pb}$ and $\mathrm{Zn}$ have been influenced by human contamination since the mid-1980s. Based on enrichment factors, $\mathrm{Cd}$ reached moderate enrichment while $\mathrm{Pb}$ and $\mathrm{Zn}$ pollution were minimal. The anthropogenic $\mathrm{Cd}$ fluxes to Lake Qinghai sharply increased from 0.03 to $0.17 \mathrm{mg} / \mathrm{m}^{2} / \mathrm{yr}$ after the mid-1980s, mainly derived from non-ferrous metal smelting in Gansu Province. The timing is similar to other lacustrine sediments from China corresponding with the initial Reform and Opening-up. We found that the fluxes of anthropogenic $\mathrm{Cd}$ to lakes were lower in northwest China than other region, primarily attributed to regional industrial emission, and phosphate fertilizers and manure applied in agriculture.

\section{Declarations}

Availability of data and materials The datasets used or analyzed during the current study are available from the corresponding author on reasonable request.

Authors' contributions S.L, W.S, and Z.Z designed the study process and reviewed the work; R.C and D.N performed the fieldwork; Z.N performed the geochemical analysis. W.S and S.L led the writing of the paper, all authors contributed to discussions and writing of the manuscript. All authors revised and reviewed the drafts and gave final approval for publication.

Funding This research was supported by the Second Tibetan Plateau Scientific Expedition and Research Program (STEP) (No.2019QZKK0202), the National Natural Science Foundation of China (No.41702380), the Philosophy and Social Sciences Project for Colleges and Universities in Jiangsu Province (2020SJA0734).

Compliance with ethical standards

Competing interests The authors declare that they have no competing interests.

Ethics approval and consent to participate Not applicable.

Consent for publication Not applicable.

\section{References}

1. Appleby PG (2001) Chronostratigraphic Techniques in Recent Sediments. In: Last W, Smol J (Editors), Tracking Environmental Change Using Lake Sediments. Developments in Paleoenvironmental Research. Springer Netherlands, pp. 171-203

2. Bi X, Feng X, Yang Y, Qiu G, Li G, Li F, Liu T, Fu Z, Jin Z (2006) Environmental contamination of heavy metals from zinc smelting areas in Hezhang County, western Guizhou, China. Environ Int 32:883-890 
3. Bindler R, Rydberg J, Renberg I (2011) Establishing natural sediment reference conditions for metals and the legacy of long-range and local pollution on lakes in Europe. J Paleolimnol 45:519-531

4. Bing H, Wu Y, Zhou J, Li R, Wang J (2016) Historical trends of anthropogenic metals in Eastern Tibetan Plateau as reconstructed from alpine lake sediments over the last century. Chemosphere 148:211-219

5. Birch GF (2017) Determination of sediment metal background concentrations and enrichment in marine environments - A critical review. Science of The Total Environment 580:813-831

6. Brönmark C, Hansson L-A (2002) Environmental issues in lakes and ponds: current state and perspectives. Environ Conserv 29:290-307

7. Chen H, Teng Y, Lu S, Wang Y, Wang J (2015) Contamination features and health risk of soil heavy metals in China. Science of The Total Environment 512-513:143-153

8. Cheng H, Li M, Zhao C, Yang K, Li K, Peng M, Yang Z, Liu F, Liu Y, Bai R, Cui Y, Huang Z, Li L, Liao Q, Luo J, Jia S, Pang X, Yang J, Yin G (2015) Concentrations of toxic metals and ecological risk assessment for sediments of major freshwater lakes in China. J Geochem Explor 157:15-26

9. Cooke CA, Abbott MB (2008) A paleolimnological perspective on industrial-era metal pollution in the central Andes, Peru. Science of The Total Environment 393:262-272

10. Cui B, Xiao B, Li X, Wang Q, Zhang Z, Zhan C, Li X (2017) Exploring the geomorphological processes of qinghai lake and surrounding lakes in the northeastern tibetan plateau, using multitemporal landsat imagery (1973-2015). Global Planet Change 152:167-175

11. Dodson J, Li X, Ji M, Zhao K, Zhou X, Levchenko V (2009) Early bronze in two Holocene archaeological sites in Gansu, NW China. Quatern Res 72:309-314

12. Dudgeon D, Arthington AH, Gessner MO, Kawabata Z-I, Knowler DJ, Lévêque C, Naiman RJ, PrieurRichard A-H, Soto D, Stiassny MLJ, Sullivan CA (2006) Freshwater biodiversity: importance, threats, status and conservation challenges. Biol Rev 81:163-182

13. Evenset A, Christensen GN, Carroll J, Zaborska A, Berger U, Herzke D, Gregor D (2007) Historical trends in persistent organic pollutants and metals recorded in sediment from Lake Ellasjøen, Bjørnøya, Norwegian Arctic. Environ Pollut 146:196-205

14. Ferrat M, Weiss DJ, Dong S, Large DJ, Spiro B, Sun Y, Gallagher K (2012) Lead atmospheric deposition rates and isotopic trends in Asian dust during the last $9.5 \mathrm{kyr}$ recorded in an ombrotrophic peat bog on the eastern Qinghai-Tibetan Plateau. Geochim Cosmochim Acta 82:4-22

15. Gloaguen TV, Passe JJ (2017) Importance of lithology in defining natural background concentrations of $\mathrm{Cr}, \mathrm{Cu}, \mathrm{Ni}, \mathrm{Pb}$ and $\mathrm{Zn}$ in sedimentary soils, northeastern Brazil. Chemosphere 186:31-42

16. Hosono T, Alvarez K, Kuwae M (2016) Lead isotope ratios in six lake sediment cores from Japan Archipelago: Historical record of trans-boundary pollution sources. Science of The Total Environment 559:24-37

17. Jin Z, Han Y, Chen L (2010) Past atmospheric Pb deposition in Lake Qinghai, northeastern Tibetan Plateau. J Paleolimnol 43:551-563 
18. Kuwae M, Tsugeki NK, Agusa T, Toyoda K, Tani Y, Ueda S, Tanabe S, Urabe J (2013) Sedimentary records of metal deposition in Japanese alpine lakes for the last 250years: Recent enrichment of airborne Sb and In in East Asia. Science of The Total Environment 442:189-197

19. Li K, Liu E, Zhang E, Li Y, Shen J, Liuc X (2017) Historical variations of atmospheric trace metal pollution in Southwest China: Reconstruction from a 150-year lacustrine sediment record in the Erhai Lake. J Geochem Explor 172:62-70

20. Li P, Lin C, Cheng H, Duan X, Lei K (2015) Contamination and health risks of soil heavy metals around a lead/zinc smelter in southwestern China. Ecotoxicol Environ Saf 113:391-399

21. Li X, Sun N, Dodson J, Ji M, Zhao K, Zhou X (2011a) The impact of early smelting on the environment of Huoshiliang in Hexi Corridor, NW China, as recorded by fossil charcoal and chemical elements. Palaeogeography, Palaeoclimatology, Palaeoecology 305, 329-336

22. Li Y, Zhou S, Zhu Q, Li B, Wang J, Wang C, Chen L, Wu S (2018) One-century sedimentary record of heavy metal pollution in western Taihu Lake, China. Environ Pollut 240:709-716

23. Li Z, Feng X, Li G, Bi X, Sun G, Zhu J, Qin H, Wang J (2011b) Mercury and other metal and metalloid soil contamination near a $\mathrm{Pb} / \mathrm{Zn}$ smelter in east Hunan province, China. Appl Geochem 26:160-166

24. Lin Q, Liu EF, Zhang EL, Nath B, Shen J, Yuan HZ, Wang R (2018) Reconstruction of atmospheric trace metals pollution in Southwest China using sediments from a large and deep alpine lake: Historical trends, sources and sediment focusing. Sci Total Environ 613:331-341

25. Liu E, Birch G, Shen J, Yuan H, Zhang E, Cao Y (2012) Comprehensive evaluation of heavy metal contamination in surface and core sediments of Taihu Lake, the third largest freshwater lake in China. Environ Earth Sci 67:39-51

26. Liu E, Shen J (2014) A comparative study of metal pollution and potential eco-risk in the sediment of Chaohu Lake (China) based on total concentration and chemical speciation. Environ Sci Pollut Res 21:7285-7295

27. Liu EF, Zhang EL, Li K, Nath B, Li YL, Shen J (2013) Historical reconstruction of atmospheric lead pollution in central Yunnan province, southwest China: an analysis based on lacustrine sedimentary records. Environ Sci Pollut Res 20:8739-8750

28. Luo L, Ma Y, Zhang S, Wei D, Zhu Y-G (2009) An inventory of trace element inputs to agricultural soils in China. J Environ Manage 90:2524-2530

29. Mikac I, Fiket Ž, Terzić S, Barešić J, Mikac N, Ahel M (2011) Chemical indicators of anthropogenic impacts in sediments of the pristine karst lakes. Chemosphere 84:1140-1149

30. Pacyna JM, Pacyna EG, Aas W (2009) Changes of emissions and atmospheric deposition of mercury, lead, and cadmium. Atmos Environ 43:117-127

31. Ricciardi A, Rasmussen JB (2001) Extinction Rates of North American Freshwater Fauna. Conserv Biol 13:1220-1222

32. Shotyk W, Goodsite ME, Roos-Barraclough F, Frei R, Heinemeier J, Asmund G, Lohse C, Hansen TS (2003) Anthropogenic contributions to atmospheric $\mathrm{Hg}, \mathrm{Pb}$ and $\mathrm{As}$ accumulation recorded by peat 
cores from southern Greenland and Denmark dated using the 14C "bomb pulse curve". Geochim Cosmochim Acta 67:3991-4011

33. Song Y, Choi MS, Lee JY, Jang DJ (2014) Regional background concentrations of heavy metals ( $\mathrm{Cr}$, $\mathrm{Co}, \mathrm{Ni}, \mathrm{Cu}, \mathrm{Zn}, \mathrm{Pb})$ in coastal sediments of the South Sea of Korea. Science of The Total Environment 482-483:80-91

34. Sutherland RA (2000) Bed sediment-associated trace metals in an urban stream. Oahu Hawaii Environmental Geology 39:611-627

35. Taylor SR, McLennan SM (1995) The geochemical evolution of the continental crust. Rev Geophys 33:241-265

36. Tian H, Cheng K, Wang Y, Zhao D, Lu L, Jia W, Hao J (2012) Temporal and spatial variation characteristics of atmospheric emissions of $\mathrm{Cd}, \mathrm{Cr}$, and $\mathrm{Pb}$ from coal in China. Atmos Environ 50:157-163

37. Tian HZ, Zhu CY, Gao JJ, Cheng K, Hao JM, Wang K, Hua SB, Wang Y, Zhou JR (2015) Quantitative assessment of atmospheric emissions of toxic heavy metals from anthropogenic sources in China: historical trend, spatial distribution, uncertainties, and control policies. Atmos Chem Phys 15:1012710147

38. Vanmaercke M, Poesen J, Govers G, Verstraeten G (2015) Quantifying human impacts on catchment sediment yield: A continental approach. Global Planet Change 130:22-36

39. Wan D, Song L, Yang J, Jin Z, Zhan C, Mao X, Liu D, Shao Y (2016) Increasing heavy metals in the background atmosphere of central North China since the 1980s: Evidence from a 200-year lake sediment record. Atmos Environ 138:183-190

40. Wang P, Cao J, Han Y, Jin Z, Wu F, Zhang F (2015) Elemental distribution in the topsoil of the Lake Qinghai catchment, NE Tibetan Plateau, and the implications for weathering in semi-arid areas. J Geochem Explor 152:1-9

41. Xu H, Liu X, An Z, Hou Z, Dong J, Liu B (2010) Spatial pattern of modern sedimentation rate of Qinghai Lake and a preliminary estimate of the sediment flux. Chin Sci Bull 55:621-627

42. Yu X, Zhou W, Liu X, Xian F, Liu Z, Zheng Y, An Z (2010) Peat records of human impacts on the atmosphere in Northwest China during the late Neolithic and Bronze Ages. Palaeogeography, Palaeoclimatology, Palaeoecology 286, 17-22

43. Zeng H, Wu J, Liu W (2014) Two-century sedimentary record of heavy metal pollution from Lake Sayram: A deep mountain lake in central Tianshan, China. Quatern Int 321:125-131

44. Zhang H, Shan B (2008) Historical records of heavy metal accumulation in sediments and the relationship with agricultural intensification in the Yangtze-Huaihe region, China. Science of The Total Environment 399:113-120

45. Zhang S, Yang Y, Storozum MJ, Li H, Cui Y, Dong G (2017) Copper smelting and sediment pollution in Bronze Age China: A case study in the Hexi corridor, Northwest China. CATENA 156:92-101

\section{Figures}




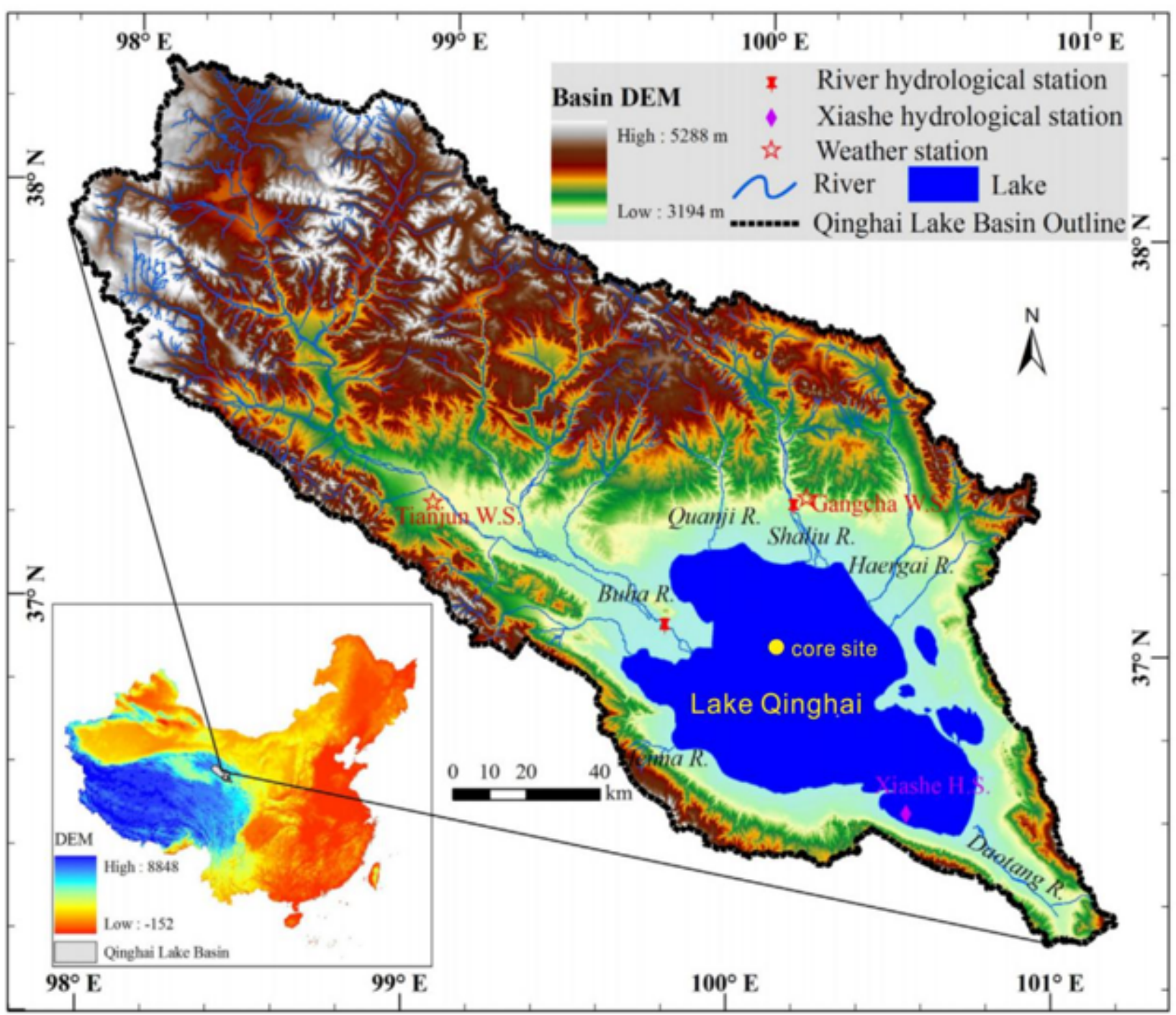

\section{Figure 1}

Lake location and sampling site (modified by Cui et al., 2017). Note: The designations employed and the presentation of the material on this map do not imply the expression of any opinion whatsoever on the part of Research Square concerning the legal status of any country, territory, city or area or of its authorities, or concerning the delimitation of its frontiers or boundaries. This map has been provided by the authors. 

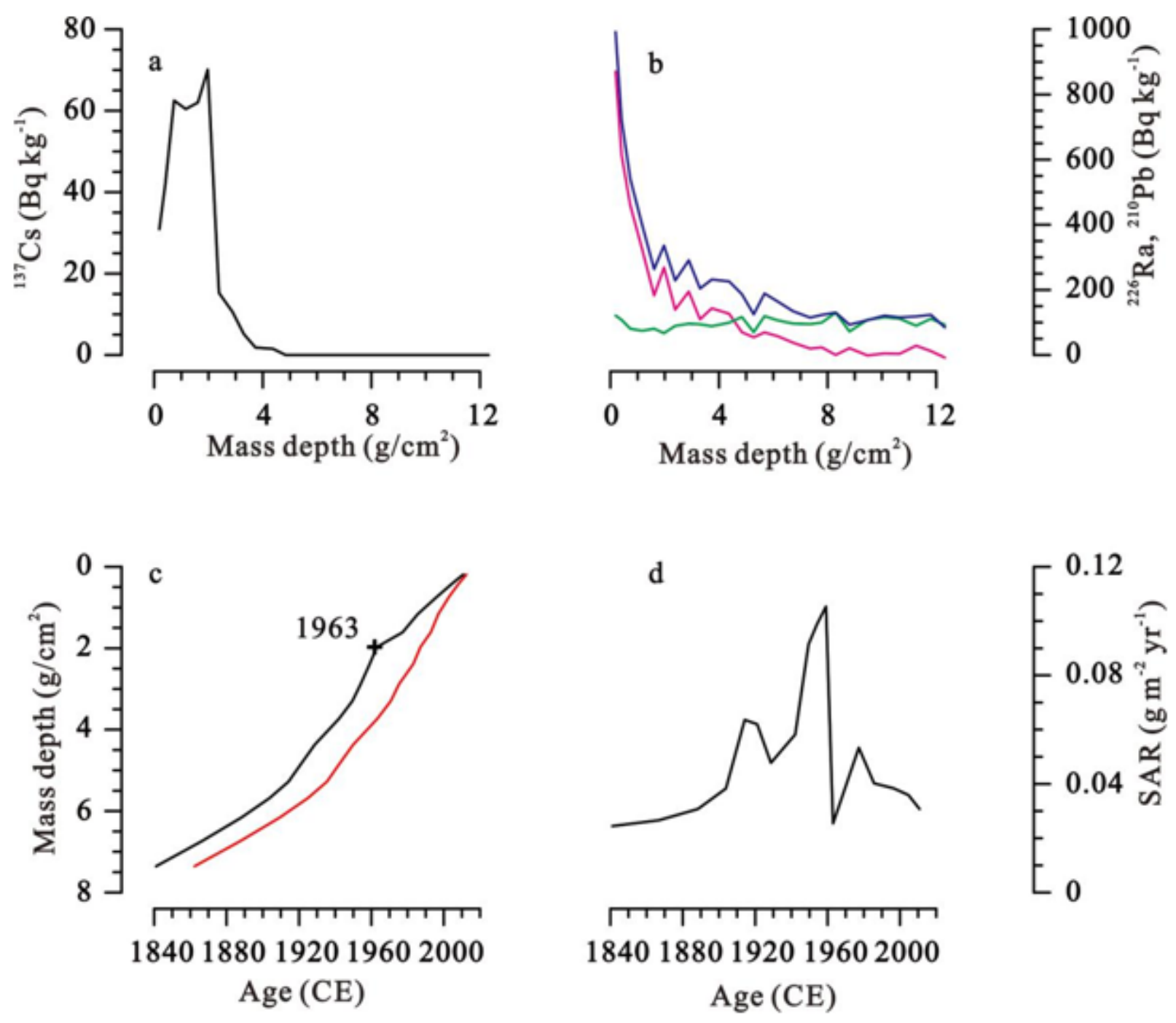

Figure 2

Variations of (a) 137Cs, (b) 226Ra (green line), 210Pbtot (purple) and 210Pbex (pink) activities, and (c) chronology (red line represents the CRS age model, and black one represents the compositional CRS age model), and (d) sediment accumulation rate (SAR) of Core QH-9. 


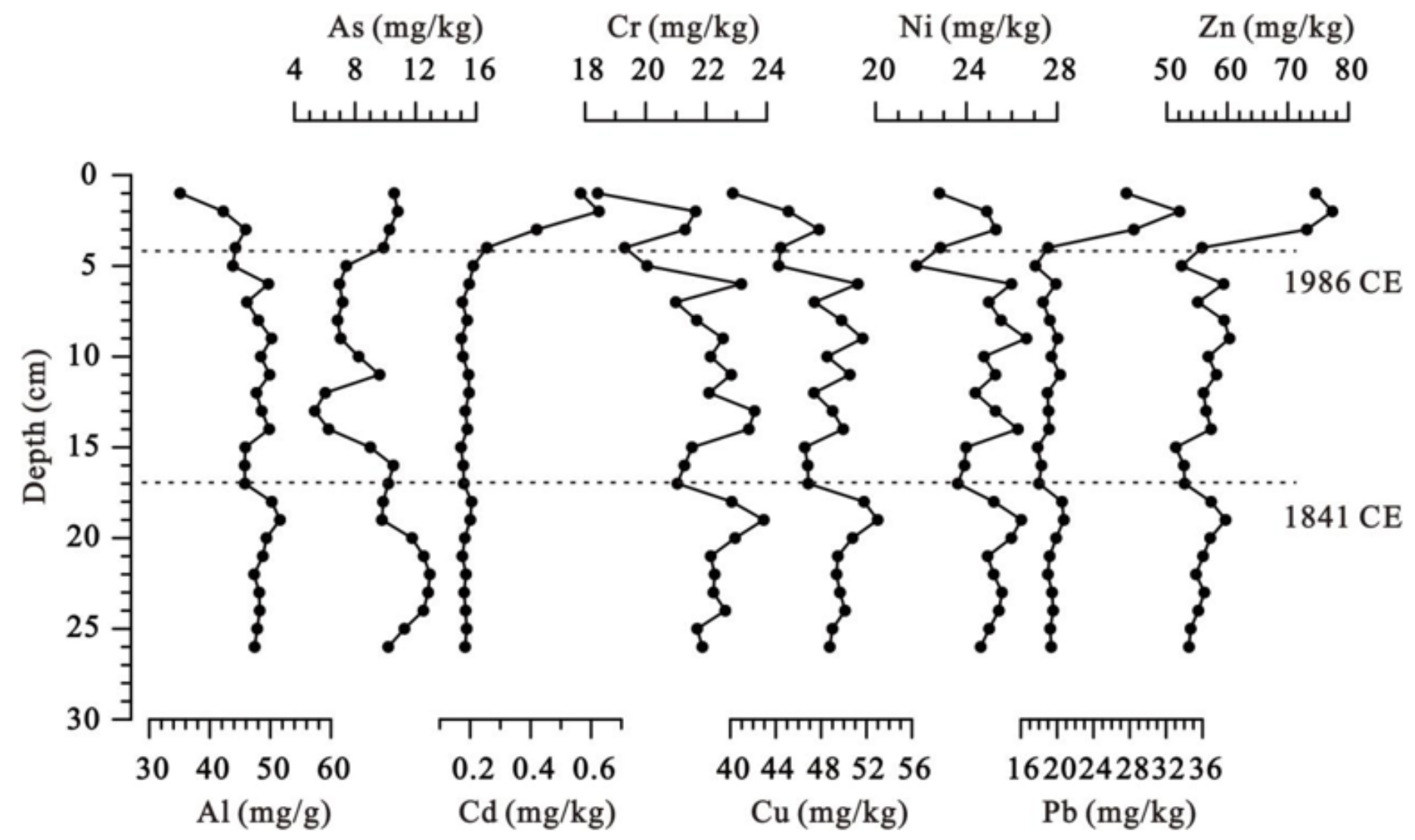

Figure 3

Vertical variations of $\mathrm{Al}$ and trace metal concentrations in sediments of Core $\mathrm{QH}-9$. 


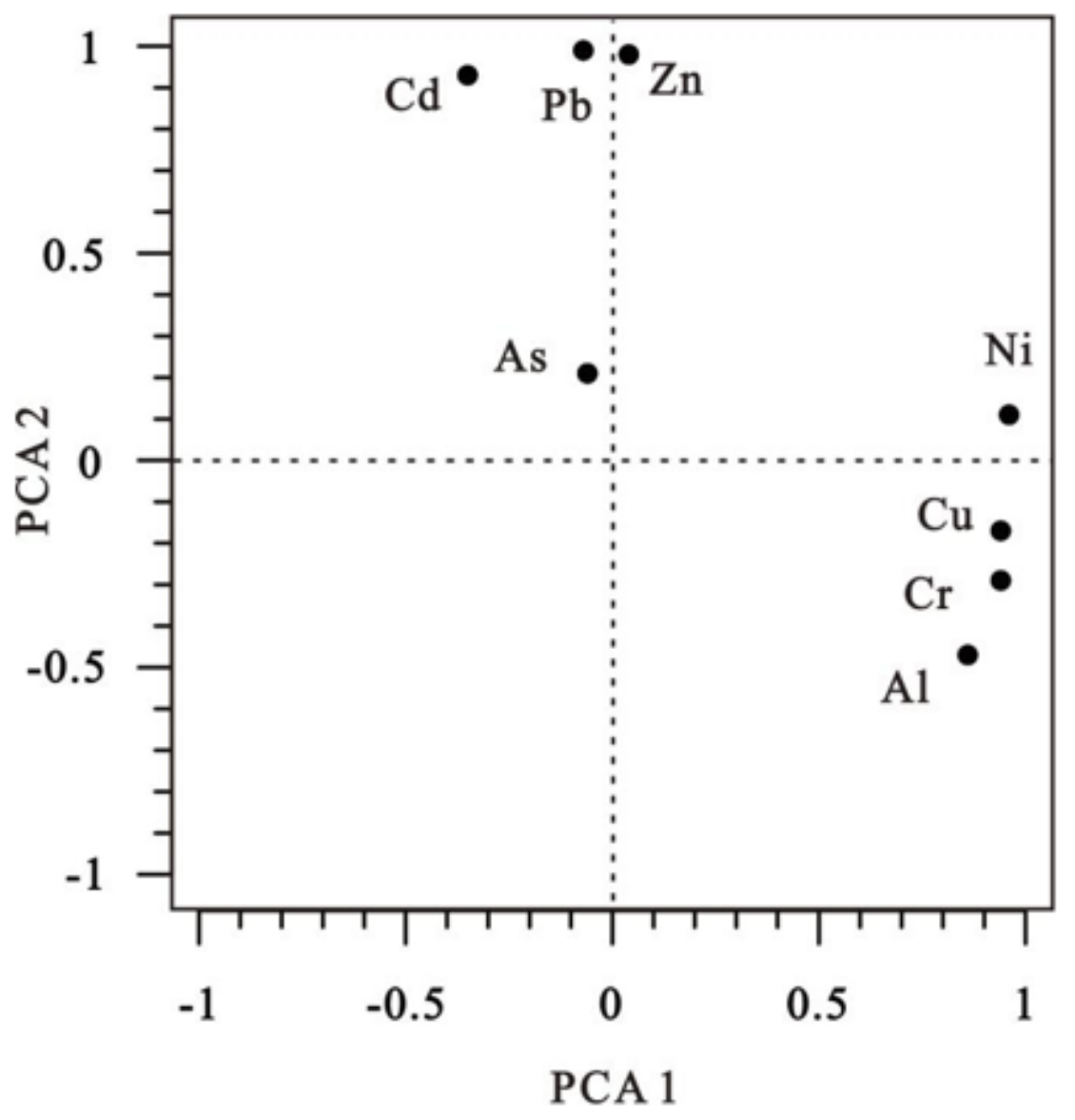

Figure 4

Factor analysis scores plot (PCA1 vs. PCA2) for the metals in the sediment of Lake Qinghai. 


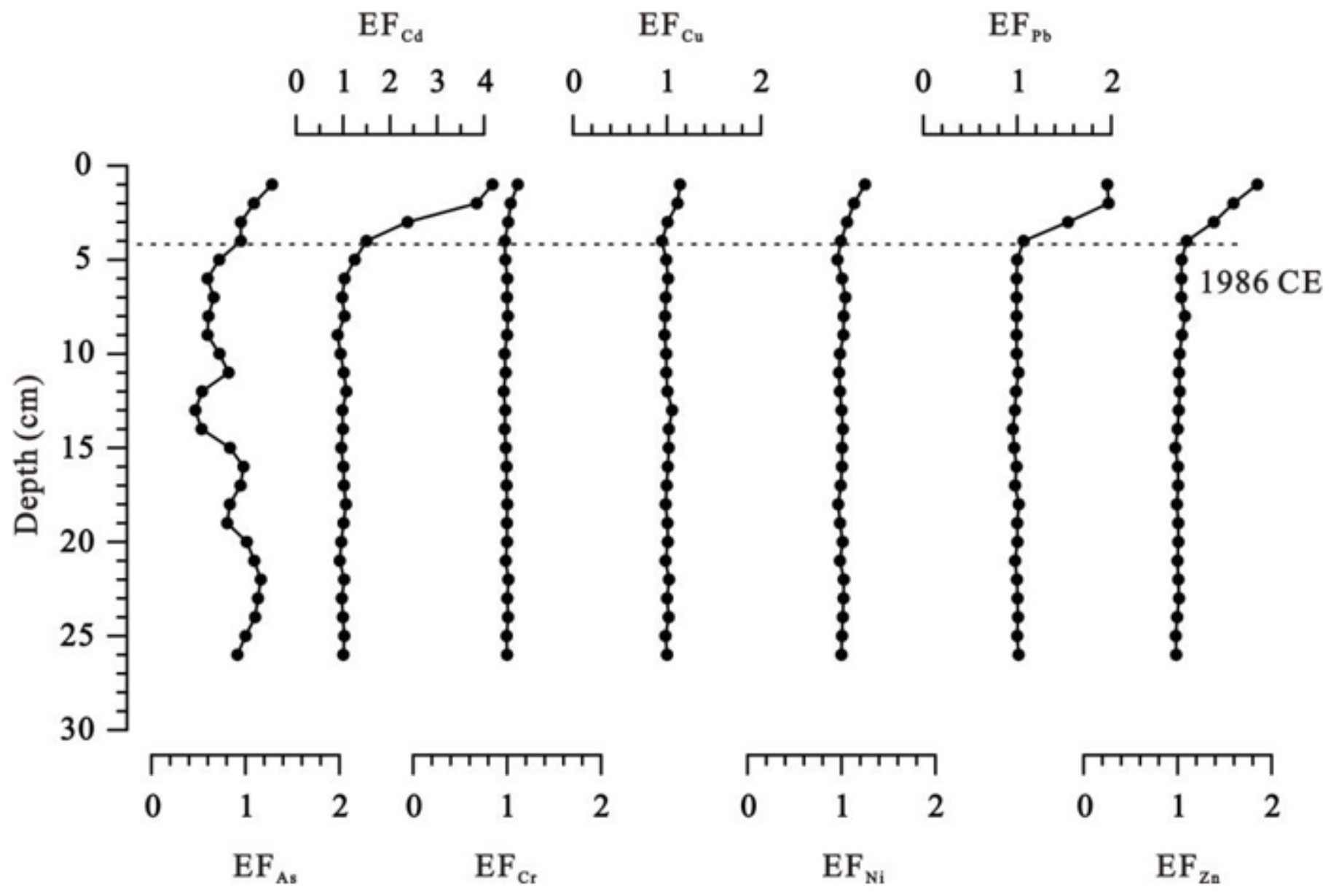

Figure 5

Temporal variations of the trace metal enrichment factors. 


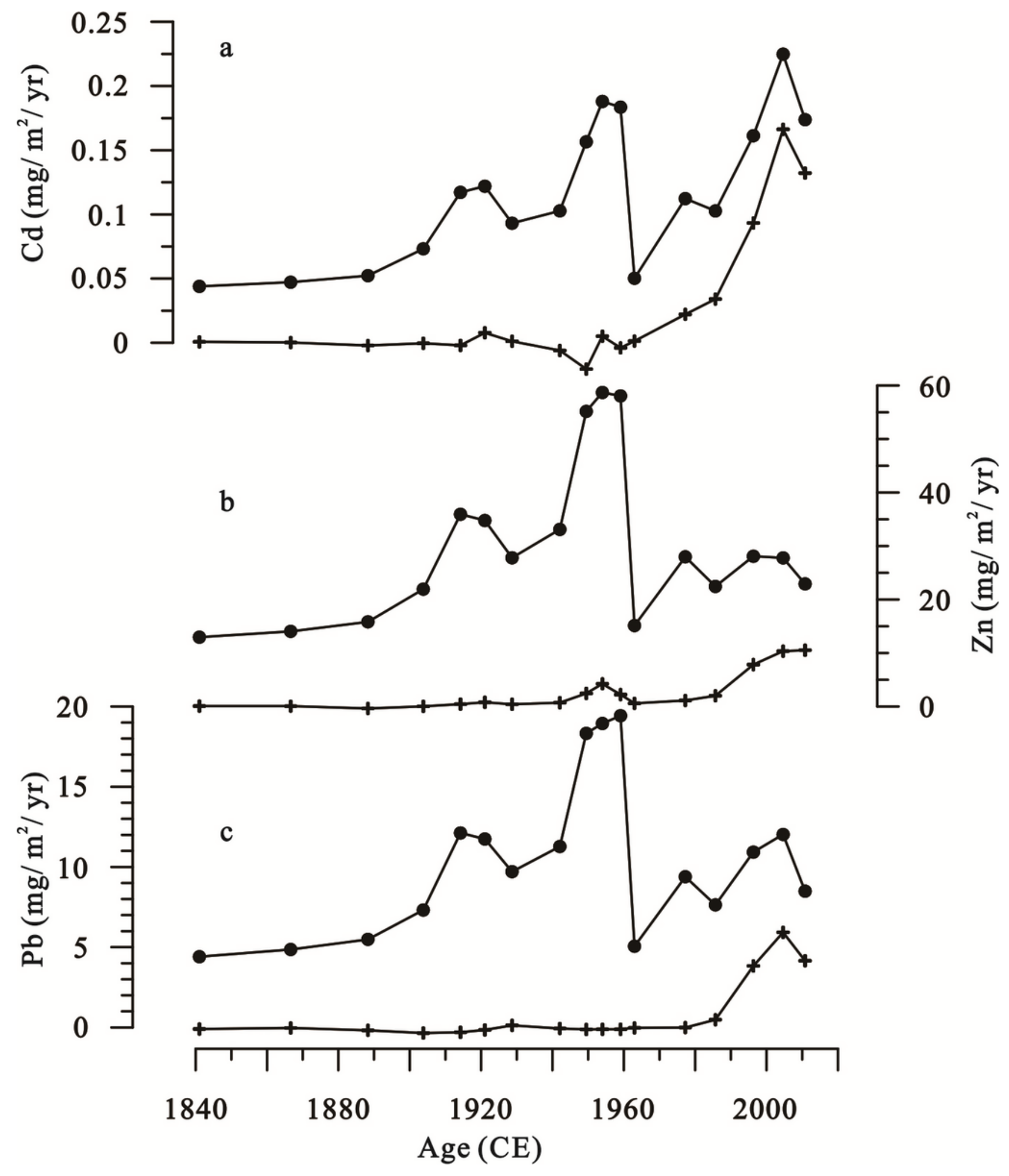

Figure 6

Sedimentary fluxes of $\mathrm{Cd}, \mathrm{Zn}$ and $\mathrm{Pb}$ (filled circles) and anthropogenic sources referenced to the preindustrical background (crosses) in the sediment core from Lake Qinghai. 


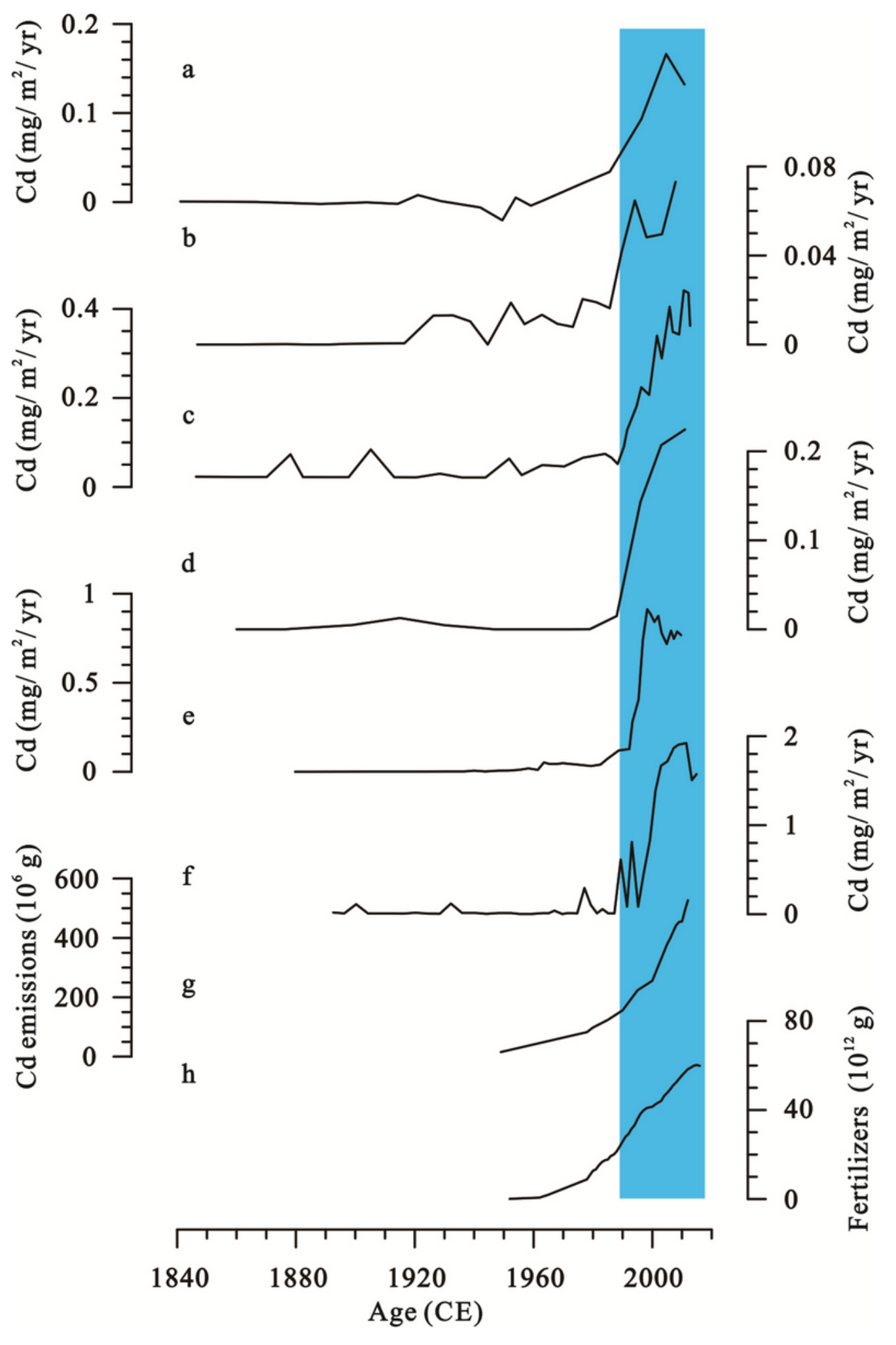

Figure 7

Historical trends in the mass accumulation fluxes of anthropogenic Cd in Chinese lakes (a. Lake Qinghai; b. Lake Sayram (Zeng et al., 2014); c. Lake Gonghai (Wan et al., 2016; d. Lake Caohaizi (Bing et al., 2016); e. Lake Lugu (Lin et al., 2018); f. Lake Taihu (Li et al., 2018)), industrial Cd emissions (g, Tian et al., 2015) and fertilizer used in agriculture in China during the last 60 years. 